\title{
The United Nations Security Council Resolution 2417 on Starvation and Armed Conflicts and Its Limits: Tigray/Ethiopia as an Example
}

\author{
Fisseha Fantahun Tefera \\ Ph.D. Candidate, School of Global Studies, University of Gothenburg, \\ Gothenburg, Sweden \\ fisseha.tefera@gu.se
}

\begin{abstract}
The 2018 United Nations Security Council Resolution 2417 makes a significant contribution to the growing normative framework that is considering famines as subjects of global peace and security. The Resolution's limits and blind spots in connection with non-state armed groups, the use of human shields, and the politics of humanitarian intervention are raised and discussed in this essay. The current armed conflict and risk of famine in Ethiopia is used an example for these discussions.
\end{abstract}

\section{Keywords}

famine - starvation - UN Security Council Resolution 2417 - armed conflicts - Ethiopia - Tigray

By ' $[r]$ ecognising the need to break the vicious cycle between armed conflict and food insecurity', the 2018 United Nations Security Council Resolution $2417^{1}$ makes a strong contribution to the growing normative framework that is putting (mass) starvation, famine, and hunger into the realm of (international)

1 UNSC Res. 2417, May 2018, (1). 
peace and security. Despite the need for more scholarly and policy focus on the connections, this Resolution, read together with the 2019 Amendment $^{2}$ to the Rome Statute that recognised the use of starvation in non-international armed conflicts as a war crime, directly puts starvation crimes under the purview of the 2005 Responsibility to Protect $\left(\mathrm{R}_{2} \mathrm{P}\right)^{3}$ framework. The current humanitarian catastrophe in Tigray, Ethiopia, a result of the political crisis that escalated to armed conflict in November 2020, according to the UN, has put around 400,00o people in famine conditions while 1.8 million people are at the brink of famine. ${ }^{4}$

In March 2021 the Global Rights Compliance (GRC), together with the World Peace Foundation (WPF), published the paper Ethiopia: A Test Case for UN Security Council Action under Resolution 2417.5 Identifying the Tigray/ Ethiopia situation as the first case to test the preventive provisions of the Resolution (2417), GRC and WPF called for the Security Council to take measures, including assigning a UN focal point for the Resolution, urging of parties to the conflict to respect international human rights and humanitarian laws, and establishing an independent and impartial investigation mission. Here, I reflect on certain blind spots and limits of the Resolution that hinder its ability to meaningfully 'address conflict-induced food insecurity, including famine, in situations of armed conflict'. 6

\section{Non-international Armed Conflicts and Starvation}

The significant achievements made in eradicating famine from the face of the earth have been challenged in recent years, ${ }^{7}$ especially starting from the 2011 famine in southern Somalia and including famines (famine-like situations) in

2 World Peace Foundation (WPF), 'Starvation: Vital Amendment to the Rome Statute Unanimously Passes', 6 December 2019, https://sites.tufts.edu/reinventingpeace/2019/12/o6/ starvation-vital-amendment-to-the-rome-statute-unanimously-passes/, accessed o2 July 2021.

3 UN Responsibility to Protect, https://www.un.org/en/genocideprevention/aboutresponsibility-to-protect.shtml, accessed 17 July 2021.

4 UN News, '400,0oo in Tigray Cross "Threshold into Famine", with Nearly 2 Million on the Brink, Security Council Told', 2 July 2021, https://news.un.org/en/story/2021/o7/1095282, accessed ०5 July 2021.

5 WPF and GRC, 'Ethiopia: A Test Case for UN Security Council Action Under Resolution 2417', 4 March 2021, https://sites.tufts.edu/reinventingpeace/2021/o3/o4/ethiopia-a-test-case-for-unsecurity-council-action-under-resolution-2417/, accessed o2 July 2021.

6 UnSC Res. 2417, May 2018, (1).

7 See Alex De Waal, Mass Starvation: The History and Future of Famine (Cambridge: John Wiley \& Sons, 2018). 
Yemen, Syria, South Sudan, and currently Ethiopia. Armed conflicts in these countries have assumed the leading role in causing famine conditions and hindering famine response operations. ${ }^{8}$ In fact, in 2019, of all 135 million people globally in a situation of acute food crisis (IPC level 3) or worse, 77 million are in conflict-affected areas (in 22 countries, 21 of which are in the Middle East and Africa). ${ }^{9}$ In the absence of other significant factors (like drought), the current situation in Tigray, Ethiopia, is clear testimony of how certain forms of armed conflicts, particularly non-international armed conflicts wherein civilians are highly vulnerable, are strongly linked to famine. While the UNSC Resolution 2417 underscores this relationship, it falls short in identifying which forms of armed conflicts are particularly responsible for creating the conditions for famine. By failing to do so, the Resolution is limited in its preventive and accountability aspects.

The nature of armed conflicts, particularly in Africa, has changed over the past few decades. Now, most of these conflicts are confined inside state borders, between the state and armed non-state actors or popular protests. ${ }^{10}$ The armed conflicts (in Yemen, Syria, Somalia, South Sudan, and now Ethiopia) that drove the major famines (famine-like situations) in the past decade are characterised by this change. In Tigray, the armed conflict started in November 2020 between the central government defence forces and the Tigray region's paramilitary special police forces and militias. This did not last long, as the regional forces led by the Tigray People's Liberation Front (TPLF) left the cities. It was after this stage that reports of the humanitarian crisis began to appear as the armed conflict turned into protracted warfare between a central government's conventional military and a rebelling force adopting guerrilla tactics, bringing the armed conflict to vast areas of the region. This distinct characteristic of armed conflicts is recognised in the December 2019 amendment ${ }^{11}$ to the Rome Statute that expanded the jurisdiction of the International Criminal Court to recognise the use of starvation in non-international armed conflicts as a war crime. While the UNSC Resolution 2417 urges 'all parties' to armed

8 Brian Lander and Rebecca Vetharaniam Richards, 'Addressing Hunger and Starvation in Situations of Armed Conflict-Laying the Foundations for Peace', Journal of International Criminal Justice, 17(4) 675-698 (2019). Alex De Waal, 'The End of Famine? Prospects for the Elimination of Mass Starvation by Political Action' Political Geography, 62, 184-195 (2018). Food Security Information Network, 'Global Report on Food Crises 2020', 20 April 2020, p.22, https://www.wfp.org/publications/2020-global-report-food-crises, accessed o2 July 2021. Sebastian von Einsiedel, Louise Bosetti, James Cockayne, Cale Salih, and Wilfred Wan, 'Civil War Trends and the Changing Nature of Armed Conflict', United Nations University Centre for Policy Research, Occasional Paper No. 10, March 2017. WPF, 'Starvation'. 
conflicts to respect international humanitarian and human rights laws, its preventive and accountability provisions are by and large applicable and relevant to state actors. For instance, the sanction measure embedded in the Resolution as a preventive mechanism is known to be difficult to be effective on non-state armed groups. As a mechanism for accountability, the Resolution also urges states to undertake independent investigation, overlooking how non-state armed groups affect or deter such investigation in armed conflict contexts.

\section{Civilians and Civilian Infrastructure as Human Shields}

Reinforcing existing provisions in international human rights and humanitarian laws, the UNSC Resolution 2417 urges all parties to armed conflict to protect civilian infrastructure critical to the humanitarian operation and the livelihood of civilians. This is particularly essential in non-international armed conflicts as these forms of conflict usually take place in areas populated by civilians, thus their strong linkage with starvation. Reports from various organisations on the ongoing conflict in Tigray have claimed that parties to the armed conflict have in one way or another breached international human rights and humanitarian laws, destroying critical civilian infrastructures and livelihoods. ${ }^{12}$ According to most of these reports, the Ethiopian National Defence Force and Eritrean Defence Forces that are fighting against the TPLFled armed groups in Tigray are the primary actors killing civilians and destroying civilian infrastructure. On the other hand, the Ethiopian government has reported on different occasions that the TPLF-led forces have been using civilians and civilian infrastructure as human shields. ${ }^{13}$ The Office of the United Nations High Commissioner for Human Rights (OHCHR) and the Ethiopian Human Rights Commission (EHRC) Joint Investigation Team (JIT) also found that armed forces on both sides of the conflict have committed, among others,

12 World Peace Foundation, 'Starving Tigray: How Armed Conflict and Mass Atrocities Have Destroyed an Ethiopian Region's Economy and Food System and Are Threatening Famine', 2021, https://sites.tufts.edu/wpf/starving-tigray/, accessed o2 July 2021.

13 Giulia Paravicini, 'Ethiopian Troops Push for Regional Capital, Rebels Promise "Hell", Reuters, 18 November 2020, https://www.reuters.com/article/us-ethiopia-conflictidUSKBN27YoSB, accessed o1 July 2021. Borkena Ethiopian News, 'Ethiopia's Message to the International Community', 8 April 2021, https://borkena.com/2021/04/o8/internationalcommunity-ethiopias-message/, accessed o1 July 2021. Office of the Prime Minister, Federal Democratic Republic of Ethiopia, 'Categorizing “Tigray People's Liberation Front (TPLF)” and "Shene" as Terrorist Organisations', Press Release, 1 May 2021, https://www.pmo.gov.et/ media/documents/Categorizing_TPLF_Shene_as_Terrorist_Groups.pdf, accessed o1 July 2021. 
attacks on civilians and civilian objects and caused impediment and delay to humanitarian assistance. ${ }^{14}$

Despite the difficulty in establishing accountability and responsibility at this stage, it is important to recognise the relationship between the use of civilians and civilian infrastructure as human shields vis-à-vis the destruction of critical civilian infrastructure and livelihoods in armed conflicts. Under international humanitarian law, the use of human shields in armed conflicts amounts to a war crime. ${ }^{15}$ Rightfully so, Resolution 2417 ' $[$ s] trongly condemns the unlawful denial of humanitarian access and depriving civilians of objects indispensable to their survival ...' and ' $[u]$ rges all parties to protect civilian infrastructure which is critical to the delivery of humanitarian aid and to ensure the proper functioning of food systems and markets' ${ }^{16}$ While attention to the responsibility of protecting civilian infrastructure is essential, a more specific yet critical aspect of this, that is, the use of civilians and civilian infrastructure as shields, a strategy often used by non-state armed groups, is overlooked in the Resolution.

An additional blind spot in Resolution 2417 concerns the politics of humanitarian access and the role of foreign countries in non-international armed conflicts. Humanitarian access to areas affected by armed conflicts is a key factor in responding to the risk of famine and has the potential to avert starvation/ famine casualties. Even though armed conflict and other factors create the conditions for famine, it is argued that failure in response is what results in famine casualties. ${ }^{17}$ This is recognised by the Resolution which ' $\left.s\right]$ trongly condemns the unlawful denial of humanitarian access ... wilfully impeding relief supply and access for responses to conflict-induced food insecurity in situations of armed conflict'. ${ }^{18}$ Since the start of the armed conflict in Tigray, the issue of unfettered humanitarian access has been a source of political and diplomatic strife between the Ethiopian government and international aid agencies and

14 OHCHR and EHRC, 'Report of the Ethiopian Human Rights Commission (E HRC)/Office of the United Nations High Commissioner for Human Rights (o HCHR) Joint Investigation', o3 November 2021, https://www.ohchr.org/EN/NewsEvents/Pages/DisplayNews.aspx?NewsID= 27756\&LangID=E, accessed o5 November 2021.

15 See ICRC, Customary IHL Database, 'Rule 97. Human Shields', https://ihl-databases.icrc.org/ customary-ihl/eng/docs/vi_rul_rule97, accessed o5 July 2021.

16 UnSC Res. 2417, May 2018, (3-4).

17 Stephen Devereux, 'Why Does Famine Persist in Africa?', Food Security 1(25) (2009).

18 UNSC Res. 2417, May 2018, (3). 
Western countries. Despite mounting pressure including sanctions by the United States, aid agencies still seek unfettered humanitarian access to reach those in remote areas. ${ }^{19}$

The Ethiopian Prime Minister, Abiy Ahmed, finds some of the elements of the continuous pressure for unfettered access to be against the sovereignty and national interest of the country. In a recent interview, ${ }^{20}$ Ahmed recalled how through the cover of humanitarian access during the $1984 / 85$ famine the then insurgent TPLF forces were strengthened by foreign countries to ultimately overthrow the Derg regime. ${ }^{21}$ He further pointed out his suspicion over the unreasonable demands of international non-governmental organisations for large quantities of highly sophisticated communication gadgets, and also their request to access insecure areas without the escort of the defence forces and even the opening of a special corridor. For him, this is linked with foreign countries that have other political interests that is akin to what happened in the 1980s. Substantiating such claims about subversive activities under the cover of humanitarian operations is a challenging task. For instance, declassified documents evidencing the policy of US and UK governments' use of humanitarian operations as a cover to support insurgents during the $1984 / 85$ famine to overthrow the USSR-friendly Derg regime in Ethiopia came out in recent years. ${ }^{22}$ In this regard, it is difficult to fully disregard the concerns and suspicions Ahmed raised regarding the politics of humanitarian access. Given the region's geopolitical location and the recently heightened great powers and Middle East countries' competition ${ }^{23}$ for influence and domination, it is crucial to look beyond the local and national actors in understanding the armed conflict and the consequent events. Unfortunately, Resolution 2417 has limitations in scope in this regard.

19 UN News, “Free, Unfettered Access” Needed to Assist Millions in War-Torn Tigray', 2 July 2021, https://news.un.org/en/story/2021/07/1095262, accessed o5 July 2021.

20 EвC Interview with PM Abiy Ahmed, YouTube, 23 June 2021, https://www.youtube.com/ watch?v=U1-MDyoTNGA, accessed o1 July 2021.

21 Derg stands for the Coordinating Committee of the Armed Forces, Police and Territorial Army.

22 Martin Plaut, 'British Plots to Overthrow the Ethiopian Government during the $1984-85$ Famine', 6 February 2018, https://talkinghumanities.blogs.sas.ac.uk/2018/02/o6/britishplots-to-overthrow-the-ethiopian-government-during-the-1984-85-famine/, accessed o5 July 2021.

23 Yoel Guzanski and Daniel Rakov, 'How Great Power Competition and Regional Rivalries are Destabilizing the Red Sea Region', 28 August 2020, https://nationalinterest.org/feature/howgreat-power-competition-and-regional-rivalries-are-destabilizing-red-sea-region-167993, accessed o5 July 2021. 
A relevant section in the Resolution, in this regard, is where it ' $[u]$ rges those with influence over parties to armed conflict to remind the latter of their obligation to comply with international humanitarian law'. ${ }^{24}$ Whereas it is appropriate to recognise 'influence' and urge the use of it to push for compliance with international humanitarian law, the Resolution overlooks how 'influence' contributes to armed conflicts and humanitarian crises. Countries that are currently home to almost all of those in acute food crisis (IPC level 3) or worse mainly due to armed conflict are located in Africa and the Middle East. These are areas with a long history of foreign intervention, coupled with weak political and economic structures. ${ }^{25}$ To fully realise its aim and purpose of preventing starvation in armed conflict areas, the Resolution needs to recognise how countries that have 'influence' over the parties to the armed conflict also use their influence to advance their interests, usually contributing to the armed conflict.

Famines and famine-like situations we have seen over the past decade, including the current situation in Ethiopia, represent a watershed for the significant achievements made over the past couple of decades in eradicating famine catastrophes. On the plus side, the normative space has seen significant gains in recognising famines and starvation as man-made disasters, including the recognition of their strong linkage with armed conflicts through the 2018 U NSC Resolution 2417 and the 2019 Amendment to the Rome Statute, among others. These normative developments that frame starvation as a war crime even in non-international conflicts provide the context whereby the ${ }_{2005} \mathrm{R}_{2} \mathrm{P}$ three pillars (individual state responsibility, international community support, and collective action) become instrumental. This is instrumental not only as a preventive mechanism, but also as a mechanism to establish accountability and responsibility, a long-overdue assignment. Scholarly and policy work need to flesh out this existing linkage more clearly to put mass-starvation, hunger, and famine at the centre. As armed conflicts become significant drivers of famines and starvation, it is important to unpack the complexity of these armed conflicts, understand their nature, and identify actors and their roles. Doing so prevents us from simplistic and localised framing of famines and starvation,

24 UNSC Res. 2417, May 2018, (4).

25 See Elizabeth Schmidt, Foreign Intervention in Africa: From the Cold War to the War on Terror (Cambridge: Cambridge University Press, 2013), doi:10.1017/CBO9781139021371. 
which contributes to the blind spots discussed briefly above. In turn, addressing these blind spots will result in stronger and more effective normative instruments whereby the roles of non-state armed actors are understood and dealt with, the concerns of state actors are recognised and addressed, and the aspirations of the international community are achieved. Above all, it means a significant contribution to protecting civilians from mass starvation atrocities during armed conflicts. 